\section{Childhood and adolescent obesity and adult mortality: a systematic review of cohort studies}

\author{
Obesidade na infância e adolescência e \\ mortalidade na idade adulta: uma revisão \\ sistemática de estudos de coorte
}

Fernando Adami 1

Francisco de Assis Guedes de Vasconcelos 2

\footnotetext{
${ }^{1}$ Faculdade de Saúde Pública, Universidade de São Paulo, São Paulo, Brasil.

2 Centro de Ciências da

Saúde, Universidade

Federal de Santa Catarina,

Florianópolis, Brasil.

Correspondence

F. Adami

Programa de Pós-graduação em Saúde Pública,

Faculdade de Saúde Pública Universidade de São Paulo.

Av. Dr. Arnaldo 715,

São Paulo, SP

01246 904, Brasil.

adamifernando@uol.com.br
}

\section{Abstract}

This systematic review addressed cohort studies on obesity in childhood and adolescence and adult mortality, published from January 1990 to March 2007. We searched the PubMed database with the following uniterms: obesity, mortality, child, adolescent; obesity and mortality; overweight and mortality. References were also analyzed. The age limit was 2 to 18 years. Quality of the articles was assessed, and eight were identified and reviewed. All used weight and stature for determination of obesity, and seven used body mass index (BMI). The quality score varied from 9 to 17. Evidence of association between obesity in childhood and adolescence and adult mortality should be viewed with caution. Use of BMI and potential confounders were discussed. Further research is needed to analyze the relationship between childhood and adolescent obesity and adult mortality.

Obesity; Overweight; Mortality; Child; Adolescent

\section{Introduction}

Obesity can be defined as excess body fat in the individual 1,2 . It is considered a chronic, noncommunicable disease, like diabetes, cardiovascular diseases, and cancer. Such diseases are currently the principal causes of death in both developed and developing countries, thus making them the largest contemporary public health problem ${ }^{3}$.

The consequences of obesity in adulthood are well known. Obesity has both a direct influence on mortality and acts as a risk factor for various diseases and health problems. It is associated with non-fatal but debilitating illnesses such as respiratory difficulties, musculoskeletal disorders, skin problems, and infertility. Meanwhile the association with fatal chronic diseases includes cardiovascular diseases, conditions related to insulin resistance and non-insulin-dependent diabetes, certain types of cancer, and gall bladder disease. Psychological consequences such as body dissatisfaction and eating disorders, in addition to social consequences such as prejudice, are also associated with obesity 4,5 .

Another concern related to obesity is its international prevalence. According to the World Health Organization (WHO) 5 , worldwide obesity prevalence has increased at an alarming rate. In the last two decades, what used to be considered a disease of the developed countries now also affects individuals from developing countries, 
at higher growth rates than in the wealthy countries 5,6 .

The epidemic's impact on national economies and individual health makes the study of the causes of obesity crucially important, in order to take measures to orient its control, prevention, and treatment 7 .

However, studies on obesity in the first two decades of life are relatively recent as compared to those on obesity in adulthood. Two aspects should be highlighted when considering the theme's importance in children and adolescents: (1) the association between overweight and obesity and mortality and morbidity and (2) the increase in the world prevalence in this younger age bracket.

Various studies have dealt with the increase in prevalence of childhood and adolescent obesity in recent decades 8,9 , highlighting the importance of its increasingly early prevention. However, few studies have focused on the association between childhood and adolescent obesity and adult mortality. Based on the above, the aim of this article was to identify and analyze studies on the relationship between obesity in childhood and adolescence and mortality in adulthood.

\section{Method}

A systematic review was performed in the electronic database of the National Library of Medicine (MEDLINE) with the objective of identifying and analyzing studies on the theme "association between obesity in childhood and adolescence and mortality in adulthood". The uniterms used were: obesity, mortality, child, and adolescent, all according to Medical Subject Headings (MeSH). Searches were also conducted using only the terms obesity and mortality, as well as overweight and mortality. The electronic article search used the following limits: studies with humans, published from January 1, 1990, to March 1, 2007, and involving individuals from 2 to 18 years of age. The initial search yielded 718 articles.

The following eligibility criterion was defined: cohort studies plus the requirement that the article present a comparison of mortality data between exposed (obesity) and unexposed individuals (without obesity). Studies were excluded that approached the association between mortality and variables related to the fetal period, as were studies that verified mortality in age brackets other than those proposed in the current article.

The bibliographic references in the selected articles were also analyzed. Thus, articles considered relevant were selected for analysis, even if they had not been located in the electronic search. Only eight studies were finally identified that met the eligibility criteria.

Evaluation of the articles' quality was based on the method proposed by Downs \& Black 10 . The authors developed a questionnaire with 27 questions divided into four groups: presentation (related to issues like clarity in the description of objectives, confounding variables, probability values), external validity (related to data extrapolation to the population where the sample was drawn), internal validity (analysis of biases, like reliability of the exposure and outcome measures, use of confounders), and study power (whether the study had sufficient power to detect an important clinical effect). Since this method has specific questions on randomized clinical trials, the current study used an adapted version presented by Monteiro \& Victora 11. In this version, four questions were removed (numbers $8,13,23$, and 24), thereby allowing analyses of non-randomized studies, which includes cohort studies.

The 23 questions are on objective aspects that (according to the authors) relate to the study quality. The article either does or does not deal with what is asked in the question. The nature of the evaluation is thus objective. For each question, one applies a score of zero (0) if the article does not deal with what the question asks and one (1) if it successfully deals with it. For question 5 only, the score can reach two (2). Each article can obtain a maximum score of 24 .

\section{Results}

As shown in Table 1, for the period studied, only eight articles were identified that covered cohort studies on the relationship between childhood and adolescent obesity and adult mortality. Of these, four were relatively recent, having been published in the last five years.

All eight articles used the anthropometric variables weight and stature to determine exposure (obesity), and only one article 12 did not use body mass index (BMI). In two articles, participants' age was 18 years, and exposure was determined on the basis of reported weight and stature 13,14. Three studies analyzed individuals from 13 to 18 years of age $15,16,17$ and the other three ranged from 2 to 14 years 18,5 to 18 years 12 , and 2 to 18 years 19 .

Criteria for determining overweight and obesity differed among the studies. Yarnell et al. 14 used BMI distribution by quintiles, in which the last quintile was used to define exposure. Van Dam et al. 13 used the international reference for 
Table 1

Cohort studies that analyzed the relationship between obesity/overweight at 2 to 18 years of age and adult mortality, published from January 1,1990 , to March $1,2007$.

\begin{tabular}{|c|c|c|c|c|c|c|}
\hline Author & Country/Year & $\begin{array}{l}\text { Subjects (starting } \\
\text { year of cohort)/ } \\
\text { Follow-up period }\end{array}$ & $\begin{array}{l}\text { Exposure (criterion } \\
\text { for defining } \\
\text { overweight/ } \\
\text { obesity)/ Reference } \\
\text { group }\end{array}$ & Outcome & Results/Comments & $\begin{array}{l}\text { Quality score/ } \\
\text { Comments }\end{array}$ \\
\hline $\begin{array}{l}\text { Van Dam et } \\
\text { al. } 13\end{array}$ & United States/2006 & $\begin{array}{l}102,400 \text { women } \\
\text { from } 24 \text { to } 44 \text { years, } \\
\text { followed for } 12 \text { years }\end{array}$ & $\begin{array}{c}\text { Women's self- } \\
\text { reported weight at } \\
18 \text { years. } \\
\text { Reference: BMI from } \\
18.5 \text { to } 21.9 \mathrm{~kg} / \mathrm{m}^{2} \text {; } \\
\text { Exposure: BMI from } \\
25 \text { and } 29.9 \text {; and } \\
\text { above } 30 \mathrm{~kg} / \mathrm{m}^{2}\end{array}$ & All-cause mortality & $\begin{array}{c}\text { Relative risk } \\
\text { (confidence interval). } \\
\text { BMI from } 25 \text { to } 29.9 \text { : } \\
1.29 \text { (1.03-1.62); BMI } \\
\text { from } 30 \text { to } 34.9: 1.39 \\
\text { (1.03-1.86); BMI from } \\
35 \text { to } 40 \\
2.24 \text { (1.68-3.00). } \\
\text { Data adjusted } \\
\text { for smoking and } \\
\text { maintenance of } \\
\text { stable weight in } \\
\text { adulthood }\end{array}$ & $\begin{array}{c}\text { Score: } 15 . \\
2 \% \text { loss of sample } \\
\text { during follow-up. } \\
\text { Weight and stature } \\
\text { self-reported for } \\
18 \text { years of age } \\
\text { and adulthood. } \\
\text { Adjustments } \\
\text { for variables in } \\
\text { adulthood (lifestyle, } \\
\text { including smoking } \\
\text { and physical } \\
\text { activity, and BMI) } \\
\text { and at } 18 \text { years, } \\
\text { plus adjustment } \\
\text { for maintenance } \\
\text { of stable weight. } \\
\text { Correlation > } \\
0.84 \text { between } \\
\text { self-reported and } \\
\text { measured values } \\
\text { (118 individuals) }\end{array}$ \\
\hline $\begin{array}{l}\text { Engeland et } \\
\text { al. } 15\end{array}$ & Norway/2003 & $\begin{array}{l}227,003 \text { boys and } \\
\text { girls from } 14 \text { to } 19 \\
\text { years (1963-1975) } \\
\text { followed for } 32 \text { years }\end{array}$ & $\begin{array}{l}\text { BMI distribution for } \\
\text { the U.S. population, } \\
\text { proposed by CDC21 } \\
\text { according to gender } \\
\text { and age. } \\
\text { Reference: BMI from } \\
\text { percentiles } 25 \text { to } 74 \text {; } \\
\text { Exposure: percentile } \\
85 \text { to } 94 \text { (risk of } \\
\text { overweight); and } \geq \\
\text { 95th BMI percentile } \\
\text { (overweight) }\end{array}$ & All-cause mortality & $\begin{array}{c}\text { Relative risk } \\
\text { (confidence interval). } \\
\text { Risk of overweight: } \\
\text { O' } 1.29 \text { (1.14-1.47); } \\
\text { O } 1.31 \text { (1.14-1.52). } \\
\text { Overweight: O' } 1.82 \\
(1.48-2.25) ; \text { O } 2.03 \\
(1.51-2.72)\end{array}$ & $\begin{array}{l}\text { Score: } 17 . \\
\text { Loss of } 2 \% \text { of sample } \\
\text { during follow-up. } \\
\text { No adjustments } \\
\text { for variables like } \\
\text { smoking, stable } \\
\text { weight, and BMI } \\
\text { in adulthood. } \\
\text { Deaths occurred } \\
\text { predominantly after } \\
\text { age } 30 \text { years. }\end{array}$ \\
\hline
\end{tabular}

(continues)

overweight and obesity in the adult population (BMI $>25$ and $30 \mathrm{~kg} / \mathrm{m}^{2}$, respectively), as recommended by the WHO 20. Engeland et al. 15,16 used the Centers for Disease Control and Prevention (CDC) reference 21 , with the $85^{\text {th }}$ BMI percentile by gender and age as the cutoff point for diagnosing overweight. Gunnell et al. 18 used the $75^{\text {th }}$
BMI percentile by gender and age, with the British population as the reference. Must et al. 17 also used the $75^{\text {th }} \mathrm{BMI}$ percentile by gender and age as the cutoff for exposure, but their reference population was that of the National Health and Nutrition Examination Survey (NHANES I) 22. Nieto et al. 12 used that last weight-for-stature quintile by 


\begin{tabular}{|c|c|c|c|c|c|c|}
\hline Author & Country/Year & $\begin{array}{l}\text { Subjects (starting } \\
\text { year of cohort)/ } \\
\text { Follow-up period }\end{array}$ & $\begin{array}{l}\text { Exposure (criterion } \\
\text { for defining } \\
\text { overweight/ } \\
\text { obesity)/ Reference } \\
\text { group }\end{array}$ & Outcome & Results/Comments & $\begin{array}{l}\text { Quality score/ } \\
\text { Comments }\end{array}$ \\
\hline $\begin{array}{l}\text { Engeland et } \\
\text { al. } 16\end{array}$ & Norway/2004 & $\begin{array}{l}128,121 \text { boys and } \\
\text { girls from } 14 \text { to } 19 \\
\text { years (1963-1975). } \\
\text { Follow-up in two } \\
\text { stages: (1) until } \\
\text { adulthood, mean } \\
\text { of } 23 \text { years (range, } \\
\text { 10-34 years); ( } 2 \text { ) after } \\
\text { reaching adulthood: } \\
\text { mean of } 9.7 \text { years } \\
\text { (range, } 0-29 \text { years) }\end{array}$ & $\begin{array}{l}\text { BMI distribution } \\
\text { for U.S. population } \\
\text { proposed by CDC } 21 \\
\text { according to gender } \\
\quad \text { and age. } \\
\text { Reference: BMI from } \\
\text { percentiles } 25 \text { to } 74 \text {; } \\
\text { Exposure: percentile } \\
75 \text { to } 84 \text { (high); and } \\
\geq 85 \text { th BMI percentile } \\
\text { (very high) }\end{array}$ & All-cause mortality & $\begin{array}{c}\text { Relative risk } \\
\text { (confidence interval). } \\
\text { No adjustment for } \\
\text { adult BMI O’: high: } \\
1.2(1.0-1.5) \text {; very } \\
\text { high: 1.4 (1.0-1.8). } \\
\text { Adjustment for adult } \\
\text { BMI O': high: } 1.1 \\
\text { (0.9-1.1); very high: } \\
\text { 1.1 (0.8-1.5). } \\
\text { No adjustment for } \\
\text { adult BMI } 9 \text { : high: } \\
\text { 1.1 (0.9-1.4); very } \\
\text { high: 1.4 (1.1-1.8). } \\
\text { Adjustment for adult } \\
\text { BMI } 9: \text { high: } 1.1 \\
\text { (0.9-1.4); very high: } \\
\text { 1.3 (1.0-1.7) }\end{array}$ & $\begin{array}{l}\text { Score: } 16 \text {. } \\
\text { Loss of } 56 \% \text { of initial } \\
\text { sample. Adjustment } \\
\text { for adult BMI and } \\
\text { smoking. Among } \\
\text { persons with adult } \\
\text { BMI below } 27.5, \\
\text { no evidence of } \\
\text { association between } \\
\text { obesity in childhood } \\
\text { /adolescence and } \\
\text { adult mortality }\end{array}$ \\
\hline $\begin{array}{l}\text { Gunnell et } \\
\text { al. } 18\end{array}$ & Great Britain/1998 & $\begin{array}{c}2,399 \text { boys and girls } \\
\text { from } 2 \text { to } 14 \text { years } \\
\text { (1948) followed for } \\
57 \text { years }\end{array}$ & $\begin{array}{l}\text { BMI distribution for } \\
\text { British population } \\
\text { proposed in } 1990 \text { by } \\
\text { gender and age. } \\
\text { Reference: BMI from } \\
\text { percentiles } 25 \text { to } 49 \text {; } \\
\text { Exposure: percentile } \\
50 \text { to } 75 \text {; and }>75^{\text {th }} \\
\text { BMI percentile }\end{array}$ & $\begin{array}{l}\text { All-cause mortality, } \\
\text { cardiovascular } \\
\text { mortality, ischemic } \\
\text { heart disease } \\
\text { mortality, and stroke. } \\
\text { ICD used to describe } \\
\text { causes of death }\end{array}$ & 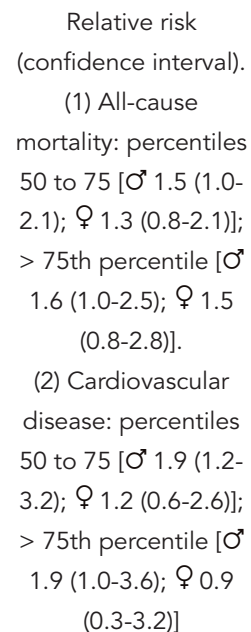 & $\begin{array}{c}\text { Score: } 15 . \\
\text { Number of losses } \\
\text { not presented. } \\
\text { However, no } \\
\text { differences found } \\
\text { between study } \\
\text { sample and initial } \\
\text { sample in BMI values } \\
\text { by gender and age, } \\
\text { or in socioeconomic } \\
\text { variables. } \\
\text { Adjustments } \\
\text { made for age and } \\
\text { socioeconomic } \\
\text { variables. }\end{array}$ \\
\hline
\end{tabular}

(continues)

gender and age, with their own study population as the reference. Lawlor et al. 19 used the cutoff points proposed by Cole et al. 23 by gender and age for overweight and obesity. For individuals 18 years or older, the reference used was $25 \mathrm{~kg} / \mathrm{m}^{2}$ and $30 \mathrm{~kg} / \mathrm{m}^{2}$.

There was less heterogeneity in relation to outcome. All the studies verified all-cause (total) mortality, except for Lawlor et al. 19, who focused only on deaths from ischemic heart disease and stroke. Gunnell et al. 18 also determined causes of death from cardiovascular disease and Must et al. 17 from coronary heart disease.

The quality score varied from 9 in Must et al. 17 to 17 for the studies by Engeland et al. 15 and Nieto et al. 12. Questions on sample representativeness had the most zero (0) scores among the studies, along with the question on study power. This question reflects whether the study is capable of identifying differences between the groups 
Table 1 (continued)

\begin{tabular}{|c|c|c|c|c|c|c|}
\hline Author & Country/Year & $\begin{array}{l}\text { Subjects (starting } \\
\text { year of cohort)/ } \\
\text { Follow-up period }\end{array}$ & $\begin{array}{l}\text { Exposure (criterion } \\
\text { for defining } \\
\text { overweight/ } \\
\text { obesity)/ Reference } \\
\text { group }\end{array}$ & Outcome & Results/Comments & $\begin{array}{c}\text { Quality score/ } \\
\text { Comments }\end{array}$ \\
\hline Must et al. 17 & United States/1992 & $\begin{array}{c}508 \text { boys and girls } \\
\text { from } 13 \text { to } 18 \text { years } \\
\text { (1922-1935) followed } \\
\text { for } 55 \text { years }\end{array}$ & $\begin{array}{l}\text { BMI distribution } \\
\text { for U.S. population } \\
\text { proposed by } \\
\text { NHANES I } 22 \\
\text { according to gender } \\
\text { and age. } \\
\text { Reference: BMI from } \\
\text { percentiles } 25 \text { to } 50 \text {; } \\
\text { Exposure: } \mathrm{BMI}>75 \text { th } \\
\text { percentile }\end{array}$ & $\begin{array}{l}\text { All-cause mortality, } \\
\text { from coronary } \\
\text { heart disease, } \\
\text { cerebrovascular } \\
\text { atherosclerosis, } \\
\text { colorectal cancer, } \\
\text { and breast cancer. } \\
\text { ICD-9 used to } \\
\text { describe causes of } \\
\text { death }\end{array}$ & 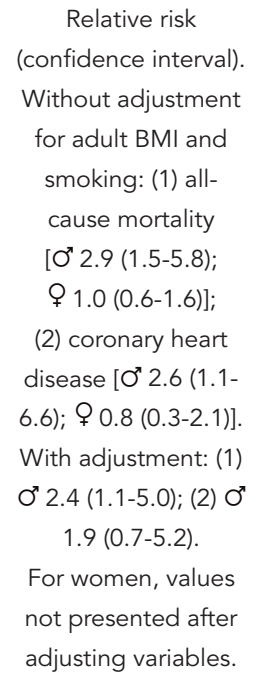 & $\begin{array}{l}\text { Score: } 9 \text {. } \\
\text { Loss of } 16 \% \text { of initial } \\
\text { sample. Adjustment } \\
\text { made for adult BMI } \\
\text { and smoking. Adult } \\
\text { weight and stature } \\
\text { were obtained by } \\
\text { self-reporting. Small } \\
\text { number of deaths } \\
\text { (161 in all), which } \\
\text { may influence the } \\
\text { relative risk value }\end{array}$ \\
\hline $\begin{array}{l}\text { Yarnell et } \\
\text { al. } 14\end{array}$ & England/2000 & $\begin{array}{c}2,335 \text { men from } 45 \\
\text { to } 59 \text { years (1979- } \\
\text { 1983) followed for } \\
14 \text { years }\end{array}$ & $\begin{array}{l}\text { Men's self-reported } \\
\text { weight at } 18 \text { years. } \\
\text { Reference: } 1 \text { st } \\
\text { quintile of BMI } \\
\text { distribution at } 18 \\
\text { years; Exposure: } \\
\text { last quintile of BMI } \\
\text { distribution at } 18 \\
\text { years }\end{array}$ & All-cause mortality & $\begin{array}{c}\text { Odds ratio } \\
\text { (confidence interval): } \\
1.29(0.93-1.79)\end{array}$ & $\begin{array}{l}\text { Score: } 12 \text {. } \\
\text { Loss of } 19 \% \text { of initial } \\
\text { sample. Relationship } \\
\text { between weight at } \\
18 \text { years and adult } \\
\text { weight was weak } \\
(r=0.34) \text {. Only } 41 \\
\text { men (1.8\%) had } \\
\text { BMI > 30 at } 18 \\
\text { years and there } \\
\text { was low prevalence } \\
\text { of individuals that } \\
\text { had never smoked } \\
\text { in adulthood. } \\
\text { Adjustment made for } \\
\text { age, smoking, and } \\
\text { social class. }\end{array}$ \\
\hline
\end{tabular}

(continues)

with $95 \%$ certainty. Only the studies by Van Dam et al. 13 and Engeland et al. 15,16 had scores of 1 on this question.

Engeland et al. 15,16, Gunnel et al. 18, and Must et al. 17 found that the risk of death in adulthood was $30,40,50$, and $190 \%$ greater, respectively, for boys who were more exposed to overweight and obesity during childhood and adolescence as compared to unexposed boys. Importantly, Must et al. 17 used a small sample, which may have influenced the risk values.
This risk is already higher when using the $75^{\text {th }}$ percentile as the cutoff, lower than the cutoffs normally used in population surveys (i.e., 85th percentile for overweight 21,22). Yarnell et al. 14 and Nieto et al. 12 did not find a higher probability of death when they compared boys exposed (versus not exposed) to excess weight in childhood and adolescence. However, Yarnell et al. 14, obtained the anthropometric measurements at 18 years of age through self-reported information from the interviewees, meaning that the in- 


\begin{tabular}{|c|c|c|c|c|c|c|}
\hline Author & Country/Year & $\begin{array}{l}\text { Subjects (starting } \\
\text { year of cohort)/ } \\
\text { Follow-up period }\end{array}$ & $\begin{array}{l}\text { Exposure (criterion } \\
\text { for defining } \\
\text { overweight/ } \\
\text { obesity)/ Reference } \\
\text { group }\end{array}$ & Outcome & Results/Comments & $\begin{array}{l}\text { Quality score/ } \\
\text { Comments }\end{array}$ \\
\hline Nieto et al. 12 & United States/1992 & $\begin{array}{l}13,146 \text { boys and } \\
\text { girls from } 5 \text { to } 18 \\
\text { years (1933-1945) } \\
\text { followed for } 52 \text { years }\end{array}$ & $\begin{array}{l}\text { Weight in relation } \\
\text { to weight-for-height } \\
\text { distribution in the } \\
\text { sample itself, by } \\
\text { gender and age. } \\
\text { Reference: } \\
\text { 1st quintile of } \\
\text { distribution; } \\
\text { Exposure: last } \\
\text { quintile of } \\
\text { distribution }\end{array}$ & All-cause mortality & $\begin{array}{l}\text { Results divided } \\
\text { for pre-pubertal } \\
\text { and post-pubertal } \\
\text { individuals. Odds } \\
\text { ratio (confidence } \\
\quad \text { interval). } \\
\text { Pre-pubertal: O’ } 1.5 \\
\text { (0.9-2.7); } 91.5 \text { (0.8- } \\
\text { 3.1); all } 1.5 \text { (1.0-2.4). } \\
\text { Post-pubertal: Ơ 1.2 } \\
\text { (0.6-2.2); } \text { \& } 2.0 \text { (1.1- } \\
\text { 3.6); all } 1.6(1.0-2.4)\end{array}$ & $\begin{array}{c}\text { Score: } 17 . \\
\text { Loss of }>50 \% \text { in } \\
\text { the initial sample. } \\
\text { However, no } \\
\text { differences in growth } \\
\text { parameters between } \\
\text { study participants } \\
\text { and initial sample. } \\
\text { Adjustments made } \\
\text { for socioeconomic } \\
\text { variables (schooling, } \\
\text { marital status) and } \\
\text { smoking. } 10 \text { controls } \\
\text { matched for each } \\
\text { case. }\end{array}$ \\
\hline $\begin{array}{l}\text { Lawlor et } \\
\text { al. } 19\end{array}$ & Great Britain/2006 & $\begin{array}{l}3 \text { historical cohort } \\
\text { studies: (1) 2,586 } \\
\text { boys and girls from } \\
2 \text { to } 15 \text { years (1937- } \\
\text { 1939); (2) 1,420 } \\
\text { boys from } 9 \text { to } 12 \\
\text { years and } 15 \text { to } 18 \\
\text { years (1936-1969); } \\
\text { (3) 10,555 men and } \\
\text { women from } 16 \\
\text { to } 23 \text { years (1948- } \\
1968 \text { ). } \\
\text { Cohort } 1 \text { was } \\
\text { followed until } 2003 \text {; } \\
\text { cohorts } 2 \text { and } 3 \\
\text { followed until } 2004\end{array}$ & $\begin{array}{l}\text { For individuals } 18 \\
\text { years of age, the } \\
\text { cutoffs proposed } \\
\text { by Cole et al. } 23 \\
\text { by gender and } \\
\text { age were used } \\
\text { for overweight } \\
\text { and obesity. For } \\
\text { individuals over } 18 \\
\text { years, the reference } \\
\text { was } 25 \mathrm{~kg} / \mathrm{m}^{2} \text { and } \\
30 \mathrm{~kg} / \mathrm{m}^{2} \text {. } \\
\text { Reference: all those } \\
\text { not overweight or } \\
\text { obese; exposure: } \\
\text { All overweight and } \\
\text { obese }\end{array}$ & $\begin{array}{l}\text { Death from ischemic } \\
\text { heart disease and } \\
\text { stroke. ICD-9 and } \\
\text { ICD-10 were used. }\end{array}$ & $\begin{array}{c}\text { Relative risk } \\
\text { (confidence interval). } \\
\text { Death from ischemic } \\
\text { heart disease: cohort } \\
\text { 1: } 1.34 \text { (0.66-2.72); } \\
\text { cohort 2: } 0.89 \text { (0.28- } \\
\text { 2.84); cohort 3: } 1.44 \\
\text { (0.9-2.3); all cohorts: } \\
\text { 1.34 (0.93-1.95). } \\
\text { Death from stroke: } \\
\text { cohort 1: } 0.51 \text { (0.07- } \\
\text { 3.71); cohort 3: } \\
\text { 1.44 (0.75-2.75); all } \\
\text { cohorts: } 1.30(0.70- \\
2.42)\end{array}$ & $\begin{array}{c}\text { Score: } 13 . \\
\text { Cohort 1: loss of } \\
\text { 12\%; cohort 2: loss } \\
\text { of 56\%; cohort 3: } \\
\text { loss of } 31 \% \text {. } \\
\text { Low prevalence } \\
\text { of overweight } \\
\text { (mean of } 4.9 \% \text { ) and } \\
\text { obese individuals } \\
\text { (mean of } 0.234 \% \text {; } \\
44 \text { individuals). } \\
\text { Adjustments made } \\
\text { for age, gender } \\
\text { (cohort 1), social } \\
\text { class and smoking } \\
\text { (cohort 3) }\end{array}$ \\
\hline
\end{tabular}

BMI: body mass index; CDC: Centers for Disease Control and Prevention; ICD: International Classification of Diseases; ICD-9: International Classification of Diseases - 9th Revision; ICD-10: International Classification of Diseases - 10th Revision. NHANES I: National Health and Nutrition Examination Survey.

dividuals had to recall a period that occurred 27 to 41 years previously. Meanwhile, Nieto et al. 12 did not use either BMI as the exposure measurement or cutoff points taken from other populations.

In women, Must et al. 17 and Gunnell et al. 18 did not find an increased risk of adult mortality for girls exposed to excess weight in adolescence. However, Engeland et al. 15,16 found a 30 to $40 \%$ increase in risk of death for girls with BMI in the $85^{\text {th }}$ percentile or greater, and an increase of $100 \%$ for those with BMI greater than or equal to the $95^{\text {th }}$ percentile. Van Dam et al. ${ }^{13}$ also found a 30 to $40 \%$ increase in risk of death for women who had a BMI of 25 to $35 \mathrm{~kg} / \mathrm{m}^{2}$ at 18 years of age, and $120 \%$ for women with BMI greater than 35 at 18 years.

Meanwhile, Lawlor et al. 19 found no increased risk of adult mortality when they compared individuals with overweight or obesity (according to Cole et al. 23) to those with normal BMI.

In relation to confounders, only Engeland et al. 15 failed to use adjustments to verify the association between childhood and adolescent obe- 
sity and adult mortality. Engeland et al. 16, Must et al. 17, and Van Dam et al. 13 adjusted for BMI in adulthood. Of these last three, only Engeland et al. 16 found that after adjusting for BMI in adulthood, there was no excess mortality in men. In women, the association between overweight and obesity and mortality was not modified by the inclusion of BMI in adulthood in the study by Van Dam et al. 13 .

\section{Discussion}

The studies analyzed here can be considered heterogeneous in relation to the criterion adopted for defining exposure, ages for measuring exposure, and outcome and control for confounders. Homogeneity can be observed in the definition of outcome, i.e., the individual's death. The studies that verified cause of death used the International Classification of Diseases as the reference.

As for the sample, all the studies were derived from epidemiological studies that conducted sample designs to ensure that the population was representative, except for the second cohort in Lawlor et al. 19, whose sample was selected intentionally. Nevertheless, as discussed previously, the questions on the study's representativeness and power were the ones with the most negative scores, which in a sense places doubt on these samples' representativeness. As for losses, only Gunnell et al. 18 failed to report the number of losses from the initial sample. However, the authors made comparisons of anthropometric and socioeconomic variables with the original cohort and did not find statistically significant differences.

The follow-up period was greater than 50 years for Must et al. 17, Gunnell et al. 18, Nieto et al. 12, and Lawlor et al. 19. Meanwhile, in the studies by Engeland et al. 15,16, the follow-up was approximately 30 years. Yarnell et al. 14 and Van Dam et al. 13 followed their samples for some 15 years. Follow-up period is an important variable for analyzing the quality of these studies, since it increases the likelihood that deaths will occur. However, each cohort cited above began over the course of several years, collecting data from individuals with different ages, meaning that the follow-up periods were expressed as averages. Thus, the individuals in each study did not all have the same follow-up period.

As for diagnosis of childhood and adolescent obesity using BMI, some questions need to be analyzed. Except for the two articles by Engeland et al. 15,16, the studies all used different reference populations for defining their cutoff points. For the cutoff to determine exposure, two studies used the $75^{\text {th }}$ percentile 17,18 and another two the last quintile 12,14 , with each of the remaining studies using a different criterion.

Since 1995, WHO has recommended establishing an international criterion for diagnosing overweight and obesity 24 . In 2000, Cole et al. 23, based on BMI distribution curves for six countries, proposed cutoff points for determining overweight and obesity that could be used as an international reference. The idea of adopting this international reference was to allow comparisons of prevalence rates between different countries.

These authors further proposed determining the cutoff point based on an epidemiological criterion, with BMI for overweight and obesity at 18 years of age. Recently, Conde \& Monteiro 25, using a similar methodology, also determined cutoff points for overweight and obesity in Brazilian children and adolescents. The use of epidemiological cutoff points, based on outcomes in adulthood as the criteria, allows greater evidence in relation to determination of risk, as compared to probabilistic criteria (in which the cutoff point is defined according to the variable's distribution in the population) 23,25 .

However, even the international reference proposed by Cole et al. 23 has been criticized. Despite its sensitivity in diagnosing risk factors for cardiac diseases in American children and adolescents 26 , its sensitivity for determining overweight and obesity in children from Switzerland 27 and Sri Lanka and Australia 28 has been low, thus highlighting the fact that this reference is not sensitive for diagnosing obesity in different countries. Socioeconomic, cultural, ethnic, and maturational factors determine the BMI distribution curve and can influence the cutoff point adopted for overweight and obesity.

The age at which exposure was measured also varied greatly in the eight studies. One cross-sectional study found no influence from age at onset of obesity ( $\leq 8$ years, 12-17 years, and $\geq 18$ years) on morbidity data in adulthood 29 . Even the study by Lawlor et al. 19 found no differences in the association between BMI and mortality when analyses were performed in different age groups. Still, onset of puberty is considered a critical period for the development of obesity 30,31,32, increased insulin resistance 33,34 , and increase in central adiposity 35 . Such variables are recognized as important risk factors for cardiac diseases 36 .

The use of confounding variables was quite heterogeneous among the studies. Van Dam et al. 13, Engeland et al. 16, Must et al. 17, Yarnnell et al. 14, Nieto et al. 12, and the third cohort study by Lawlor et al. 19 performed adjustments for smoking. As for physical activity, only Van Dam et al. 13 adjusted for this variable. Gunnell et al. 18, Yarn- 
nell et al. 14, Nieto et al. 12, and Lawlor et al. 19 adjusted for socioeconomic variables. Only Van Dam et al. 13 adjusted for stable weight maintenance.

For the adult population, the literature has demonstrated the independence and importance of physical inactivity as a strong predictor of mortality 37,38 . In children and adolescents, physical inactivity has also been observed as an independent factor for increased BMI and body fat 39. Therefore, lack of adjustment for physical activity becomes one of the principal limitations of the studies analyzed here.

Van Dam et al. 13 were the only authors that adjusted for stable weight maintenance, smoking, and adult BMI. These authors found a linear association linear between BMI and all-cause mortality, and adjusting those variables did not change the direction of the results. Meanwhile, Gunnell et al. 18 found that the association between BMI and mortality was best fitted to a quadratic curve. The authors thus proposed a J-shaped curve to explain the relationship between BMI and mortality. However, variables like smoking and stable weight maintenance were not kept in the model, which raises doubts as to the J-shaped trend. The linear relationship between BMI and mortality, after adjusting for maintenance of stable weight and smoking, is already well known in the literature on adults 5,40. For children and adolescents, the scarcity of studies (only one) does not allow corroborating this tendency.

Adjusting for BMI in adulthood is extremely important for verifying the relationship between BMI and mortality in children and adolescents. Fat deposition differs between periods in life. In childhood, fat is deposited more in the lower limbs and buttocks. In adulthood, adipose tissue tends to deposit more in the trunk and abdomen, which is characterized by a high waist-hips ratio and various cardiovascular and metabolic complications 12 . Thus, the highest risk of mortality would be due to obesity in adulthood. However, the confirmation of this model by only one study 15 further raises the need to increase the research to corroborate or refute such a model.

Given the above, the evidence on the increased risk of mortality in adulthood in individuals with overweight or obesity in childhood and adolescence should be viewed with caution, although there is a tendency towards this association in males. The lack of adjustments for potential confounding variables (like physical activity, maintenance of stable weight, smoking, and adult BMI) may jeopardize the model.

In addition, two other potential problems can be identified for such studies: (1) the use of BMI to determine obesity and (2) the use of old sam- ples, in which members of the cohort were born before the mid-20th century. In relation to the first item, the waist-hips ratio in adults is a better predictor than BMI for cardiovascular disease and mortality ${ }^{41}$. In addition, studies in children have already demonstrated relationships between morbidity indicators and waist circumference 42 and intra-abdominal fat depot 43 . Thus, the use of more accurate measurements of obesity should be a priority for future studies on the association between obesity and mortality in children and adolescents. As for item 2, the fact that such cohorts were born long before the reference population deserves critical attention. In children and adolescents, the increase in prevalence of overweight and obesity has reached alarming rates in the last three decades in both developed and developing countries 44 . Thus, one cannot refute the possibility that the reference may overestimate the cutoff values for diagnosing overweight and obesity in older samples. Studies are thus needed with more recent populations.

Even given all these limitations, obesity in childhood and adolescence should be viewed as a disease with a major public health impact. Various studies have demonstrated that obese children have higher odds of becoming obese adults 45,46 . Results have also shown the increased risk of children and adolescents with overweight and obesity for developing diseases like high blood pressure 47 , high cholesterol 48 and triglycerides 49 , insulin resistance syndrome 50 , and increased carotid intima-media thickness 51 .

One of the limitations of the current study is not having worked with ages below two years. The decision not to include this age was due to issues like difficulty in determining obesity at this age and the fact that studies on associations between this age and mortality data have focused on discussions concerning the fetal period, birth weight, and maternal morphophysiological aspects 52,53 , and not obesity. In fact, the studies that have analyzed this age bracket have either not found an association with mortality 54 or have found that the association with mortality is due to catch-up growth rather than obesity at this age 55 .

Thus, one can highlight the scarcity of studies determining the risk of mortality in adulthood in relation to overweight and obesity in childhood and adolescence. There is also a clear need for studies that control for variables like physical activity, smoking, maintenance of stable weight, adult BMI, and puberty. We thus conclude that there is still no clear evidence on the association between childhood and adolescent overweight and obesity and adult mortality. 


\section{Resumo}

Esta revisão sistemática avaliou artigos de coorte sobre obesidade na infância e adolescência e mortalidade adulta, publicados entre janeiro de 1990 e março de 2007, indexados na base de dados PubMed. Os unitermos utilizados foram: obesity, mortality, child, adolescent; obesity e mortality; overweight e mortality. Referências bibliográficas também foram analisadas. Foi utilizado limite de idade entre 2 e 18 anos. A qualidade dos artigos foi determinada por meio de metodologia apropriada para avaliação de estudos de coorte. Foram encontrados e revisados oito estudos, e todos utilizaram peso e estatura para determinação da obesidade e sete usaram o indice de massa corporal (IMC). O escore de qualidade variou de 9 a 17 (escore máximo obtido $=24)$. Deve ser vista com cautela a evidência sobre o aumento do risco de mortalidade na idade adulta em indivíduos com sobrepeso ou obesidade na infância e adolescência, apesar de existir tendência dessa associação para o sexo masculino. Foram discutidos uso do IMC e variáveis de confusão utilizadas nos estudos. São necessários mais estudos que façam associação entre obesidade na infância e adolescência e mortalidade na idade adulta.

Obesidade; Sobrepeso; Mortalidade; Criança; Adolescente

\section{Contributors}

F. Adami contributed to the study idea, literature review, critical discussions on the theme and selected articles, and writing of the preliminary and final versions of the article. F. A. G. Vasconcelos contributed to the study idea, critical discussions of the theme and selected articles, and reformulations and commentary on the preliminary and final versions of the article.

\section{References}

1. Loss RJF, Bouchard C. Obesity: is it a genetic disorder? J Intern Med 2003; 254:401-25.

2. Speakman JR. Obesity: the integrated roles of environment and genetics. J Nutr 2004; 134:2090S$105 S$.

3. World Health Organization. Diet, nutrition and the prevention of chronic diseases. Geneva: World Health Organization/Food and Agricultural Organization; 2002. (WHO Technical Report Series, 916).

4. Gu D, He J, Duan X, Reynolds K, Wu X, Chen J, et al. Body weight and mortality among men and women in China. JAMA 2006; 295:776-83.

5. World Health Organization. Obesity: preventing and managing the global epidemic. Geneva: World Health Organization; 2000. (WHO Technical Report Series, 894).

6. Ogden CL, Yanovski SZ, Carroll MD, Flegal KM. The epidemiology of obesity. Gastroenterology 2007; 132:2087-102.
7. Avenell A, Broom J, Brown TJ, Poobalan A, Aucott L, Stearns SC, et al. Systematic review of long-term effects and economic consequences of treatments for obesity and implications for health improvement. Health Technol Assess 2004; 8:iii-iv.

8. Wang Y, Monteiro C, Popkin BM. Trends of obesity and underweight in older children and adolescence in the United Sates, Brazil, China, and Russia. Am J Clin Nutr 2002; 75:971-7.

9. Lobstein T, Baur L, Uauy R. Obesity in children and young people: a crisis in public health. Obes Rev 2004; 5 Suppl 1:4-85.

10. Downs SH, Black N. The feasibility of creating a checklist for the assessment of the methodological quality both of randomized and non-randomized studies of health care interventions. J Epidemiol Community Health 1998; 52:377-84.

11. Monteiro POA, Victora CG. Rapid growth in infancy and childhood and obesity in later life - a systematic review. Obes Rev 2005; 6:143-54. 
12. Nieto FJ, Szklo M, Comstock GW. Childhood weight and growth rate as predictors of adult mortality. Am J Epidemiol 1992; 136:201-13.

13. Van Dam RM, Willett WC, Manson JE, Hu FB. The relationship between overweight in adolescence and premature death in women. Ann Intern Med 2006; 145:91-7.

14. Yarnell JWG, Patterson CC, Thomas HF, Sweetnam PM. Comparison of weight in middle age, weight at 18 years, and weight change between, in predicting subsequent 14-year mortality and coronary events: Caerphilly Prospective Study. J Epidemiol Community Health 2000; 54:344-8.

15. Engeland A, Bjorge T, Sogaard AJ, Tverdal A. Body mass index in adolescence in relation to total mortality: 32-year follow-up of 227,000 Norwegian boys and girls. Am J Epidemiol 2003; 157:517-23.

16. Engeland A, Bjorge T, Sogaard AJ, Tverdal A. Obesity in adolescence and adulthood and the risks of adult mortality. Epidemiology 2004; 15:79-85.

17. Must A, Jacques PF, Dallal GE, Bajema CJ, Dietz WH. Long-term morbidity and mortality of overweight adolescents - a follow-up of the Harvard Growth Study of 1922 to 1935. N Engl J Med 1992; 327:1350-5.

18. Gunnell DJ, Frankel SJ, Nanchahal K, Peters TJ, Smith GD. Childhood obesity and adult cardiovascular mortality: a 57-y follow-up study based on the Boyd Orr cohort. Am J Clin Nutr 1998; 67: 1111-8.

19. Lawlor DA, Martin RM, Gunnel D, Galobardes B, Ebrahim S, Sandhu J, et al. Association of body mass index measured in childhood, adolescence, and young adulthood with risk of ischemic heart disease and stroke: findings from 3 historical cohort studies. Am J Clin Nutr 2006; 83:767-73.

20. World Health Organization. Obesity: preventing and managing the global epidemic. Geneva: World Health Organization; 1997. (Report of a WHO Consultation on Obesity).

21. National Center for Health Statistics. CDC growth charts: United States, 2002. http://www.cdc.gov/ growthcharts/ (accessed on Aug/2002).

22. Must A, Dallal GE, Dietz WH. Reference data for obesity: 85th and 95th percentiles of body mass index (wt $\left./ \mathrm{ht}^{2}\right)$ and triceps skinfold thickness. Am J Clin Nutr 1991; 53:839-46.

23. Cole TJ, Bellizzi MC, Flegal KM, Dietz WH. Establishing a standard definition for child overweight and obesity worldwide: international survey. BMJ 2000; 320:1-6.

24. World Health Organization Expert Committee. Physical status: the use and interpretation of anthropometric data. Geneva: World Health Organization; 1995. (Technical Report Series, 854).

25. Conde WL, Monteiro CA. Valores críticos do índice de massa corporal para classificação do estado nutricional de crianças e adolescentes brasileiros. J Pediatr (Rio J) 2006; 82:266-72.

26. Janssen I, Katzmarzyk PT, Srinivasan SR, Chen W, Malina RM, Bouchard C, et al. Utility of childhood $\mathrm{BMI}$ in the prediction of adulthood disease: comparison of national and international references. Obes Res 2005; 13:1106-15.
27. Zimmermann MB, Gübeli C, Püntener C, Molinari L. Detection of overweight and obesity in a national sample of 6-12-y-old Swiss children: accuracy and validity of reference values for body mass index from the US Centers for Disease Control and Prevention and the International Obesity Task Force. Am J Clin Nutr 2005; 79:838-43.

28. Wickramasinghe VP, Cleghorn GJ, Edmiston KA, Murphy, AJ, Abbott RA, Davies PSW. Validity of BMI as a measure of obesity in Australian white Caucasian and Australian Sri Lankan children. Ann Hum Biol 2005; 32:60-71.

29. Freedman DS, Khan LK, Dietz WH, Srinivasan SR, Berenson GS. Relationship of childhood obesity to coronary heart disease risk factors in adulthood: the Bogalusa Heart Study. Pediatrics 2001; 108: 712-8.

30. Biro FM, McMahon RP, Striegel-Moore R, Crawford PB, Obarzanek E, Morrison JA, et al. Impact of timing of pubertal maturation on growth in black and white female adolescents: The National Heart, Lung, and Blood Institute Growth and Health Study. J Pediatr 2001; 138:636-43.

31. Demerath EW, Li J, Sun SS, Chumlea WC, Remsberg KE, Czerwinski SA, et al. Fifty-year trends in serial body mass index during adolescence in girls: the Fels Longitudinal Study. Am J Clin Nutr 2004; 80:441-6.

32. Pierce MB, Leon DA. Age at menarche and adult BMI in the Aberdeen children of the 1950s cohort study. Am J Clin Nutr 2005; 81:733-9.

33. Bloch CA, Clemons P, Sperling M. Puberty decreases insulin sensitivity. J Pediatr 1987; 110:481-7.

34. Burrows RA, Leiva LB, Burgueno MA, Maggi AM, Giadrosic VR, Diaz EB, et al. Sensibilidad insulínica en niños de 6 a 15 años: asociación con estado nutricional y pubertad. Rev Méd Chil 2006; 134: 1417-26.

35. Kindblom JM, Lorentzon M, Norjavaara E, Lonn L, Brandberg J, Algelhed JE, et al. Pubertal timing is an independent predictor of central adiposity in young adult males: the Gothenburg osteoporosis and obesity determinants study. Diabetes 2006; 55:3047-52.

36. Reinehr T, De Souza G, Andler W. Longitudinal analyses among overweight, insulin resistance, and cardiovascular risk factors in children. Obes Res 2005; 13:1824-33.

37. Hu FB, Willett WC, Li T, Stampfer MJ, Colditz GA, Manson JE. Adiposity as compared with physical activity in predicting mortality among women. $\mathrm{N}$ Engl J Med 2004; 351:2694-703.

38. Pederson BK. Body mass index-independent effect of fitness and physical activity for all-cause mortality. Scand J Med Sci Sports 2007; 17:196-204.

39. Kimm SYS, Glynn NW, Obarzanek E, Kriska AM, Daniels SR, Barton BA, et al. Relation between the changes in physical activity and body-mass index during adolescence: a multicentre longitudinal study. Lancet 2005; 366:301-7.

40. Gelber RP, Kurth T, Manson JE, Buring JE, Gaziano JM. Body mass index and mortality in men: evaluating the shape of the association. Int J Obes 2007; 31:1240-7. 
41. Welborn TA, Dhaliwal SS. Preferred clinical measures of central obesity for predicting mortality. Eur J Clin Nutr 2007; 61:1373-9.

42. Maffeis C, Pietrobelli A, Grezzani A, Provera S, Tato L. Waist circumferences and cardiovascular risk factors in prepubertal children. Obes Res 2001; 9:179-87.

43. Caprio S, Hyman LD, McCarthy S, Lange R, Bronson M, Tamborlane WV. Fat distribution and cardiovascular risk factors in obese adolescent girls: importance of the intra-abdominal fat depot. Am J Clin Nutr 1996; 64:12-7.

44. Ebbeling CB, Pawlak DB, Ludwig DS. Childhood obesity: public-health crisis, common sense cure. Lancet 2002; 360:473-82.

45. Deshmukh-Taskar P, Nicklas TA, Morales M, Yang S-J, Zakeri I, Berenson GS. Tracking of overweight status from childhood to young adulthood. The Bogalusa Heart Study. Eur J Clin Nutr 2006; 60: 48-57.

46. Kvaavik E, Tell GS, Klepp KI. Predictors and tracking of body mass index from adolescence into adulthood. Arch Pediatr Adolesc Med 2003; 157:1212-8.

47. Field AE, Cook NR, Gillman MW. Weight status in childhood as a predictor of becoming overweight or hypertensive in early adulthood. Obes Res 2005; 13:163-9.

48. Srinivasan SR, Bao W, Wattigney WA, Berenson GS. Adolescent overweight is associated with adult overweight and related multiple cardiovascular risk factors: the Bogalusa Heart Study. Metabolism 1996; 45:235-40.
49. Thompson DR, Obarzanek E, Franko DL, Barton BA, Morrison J, Biro FM, et al. Childhood overweight and cardiovascular disease risk factors: The National Heart, Lung, and Blood Institute Growth and Health Study. J Pediatr 2007; 150:18-25.

50. Srinivasan SR, Myers L, Berenson GS. Predictability of childhood adiposity and insulin for developing insulin resistance syndrome (syndrome $\mathrm{X}$ ) in young adulthood. Diabetes 2002; 51:204-9.

51. Oren A, Vos LE, Uiterwaal CSPM, Gorissen WHM, Grobbee DE, Bots ML. Change in body mass index from adolescence to young adulthood and increases in carotid intima-media thickness at 28 years of age: The Atherosclerosis Risk in Young Adults study. Int J Obes 2003; 27:1383-90.

52. Huxley R, Owen CG, Whincup PH, Cook DG, RichEdwards J, Smith GD, et al. Is birth weight a risk factor for ischemic heart disease in later life? Am J Clin Nutr 2007; 85:1244-50.

53. Martyn CN, Barker DJ, Osmond C. Mother's pelvic size, fetal growth, and death from stroke and coronary heart disease in men in the UK. Lancet 1996; 348:1246-8.

54. Dipietro L, Mossberg HO, Stunkard AJ. A 40-year history of overweight children in Stockholm: lifetime overweight, morbidity, and mortality. Int J Obes Relat Metab Disord 1994; 18:585-90.

55. Eriksson JG, Forsén T, Tuomilehto J, Winter PD, Osmond C, Barker DJ. Catch-up growth in childhood and death from coronary heart disease: longitudinal study. BMJ 1999; 318:427-31.

\footnotetext{
Submitted on $05 /$ Mar/2008

Final version resubmitted on 14/May/2008

Approved on 03/Jun/2008
} 